\title{
Ideologi dan Partai Politik: Menakar Ideologi Politik Marhaenisme di PDIP, Sosialisme Demokrasi di PSI dan Islam Fundamentalisme di PKS
}

\section{Ideology and Political Parties: Measuring the Political Ideology of Marhaenism in PDIP, Democratic Socialism in PSI and Islamic Fundamentalism in PKS}

\author{
Galang Geraldy \\ Universitas Wijaya Kusuma Surabaya \\ Jl. Dukuh Kupang XXV No.54, Dukuh Kupang, Kec. Dukuhpakis, Kota SBY, Jawa Timur \\ 60225 \\ *corresponding author E-mail: Galanggerald88@uwks.ac.id
}

Diterima: 29 Oktober 2019 ; Direvisi: 18 November 2019 ; Disetujui: 18 November 2019

\begin{abstract}
ABSTRAK
Krisis ideologi dalam dinamika partai politik pasca reformasi (democratization) menjadi hal yang sangat anomali, mengingat demokrasi mensyaratkan adanya kebebasan dialektika ide-ide politik dan ruang publik yang simetris. Pertarungan partai politik secara elektoral maupun di dalam sistem politik yang kompleks rupanya hanya mengedepankan hal-hal yang sifatnya simbolik dan artifisial. Kritik antar elit, perpindahan kader antar partai dan mati lahirnya partai politik bukan semata-semata pertarungan politik yang ideologis-filosofis. Politik terdegradasi menjadi komodifikasi antar elit maupun elit dengan masyarakat. Untuk membongkar asumsi-asumsi diatas, peneliti mengangkat tiga partai politik sebagai objek penelitian yaitu PDIP, PSI dan PKS karena ketiganya dianggap memiliki diferensiasi ide dan nilai serta gagasan politik yang khas, dari latar belakang sejarah terbentuknya sampai keputusan-keputusan politik di dalam ruang publik demokrasi. Menggunakan Metode penelitian menggunakan deskriptif-kualitatif di mana menghasilkan PDIP yang memiliki landasan historisitas politik yang kuat dengan nasionalisme-marhaen memang di dalam naskah AD-ART nya sangat eksplisit mengelaborasi ide-ide Soekarno tersebut. Namun seringkali secara riil, kebijakan politik PDIP, terutama ketika di eksekutif nasional maupun lokal masih ada paradoks. PSI, karena partai baru berdiri, peneliti menyimpulkan bahwa secara teks AD-ART juga sangat eksplisit menawarkan ide-ide politik demokrasi sosial (sosialisme demokrasi), meskipun masih perlu pembuktian ketika di pemerintahan. PKS, partai yang mengalami transformasi ideologi secara transparan, yaitu dari latar belakang politik Islam Fundamentalisme menjadi Islam Moderat, di mana nilai-nilai nasionalisme-sekuler juga mulai tumbuh-kembang di partai ini pasca pemilu 2004.
\end{abstract}

Kata Kunci: Ideologi, Partai Politik, PDIP, Marhanisme, PKS, Islam Fundamentalisme, PSI, Sosialisme Demokrasi 


\begin{abstract}
The ideological crisis in the dynamics of post-reform political parties (democratization) is a very anomalous thing, considering that democracy requires dialectical freedom of political ideas and symmetrical public spaces. Electoral political party battles, as well as in complex political systems, apparently only prioritize things that are symbolic and artificial. Criticism among the elite, the movement of cadres between parties and the death of the birth of political parties are not merely ideological-philosophical political battles. Politics was degraded into the commodification of the elite and the elite with the community. To dismantle the above assumptions, the researcher appoints three political parties as research objects namely PDIP, PSI and PKS because all three are considered to have differentiation of ideas and values as well as specific political ideas, from the historical background of their formation to political decisions in the public sphere democracy. Using descriptive-qualitative research methods that produce PDIP, which has a strong foundation of political historicity with nationalism-marhaen indeed in the AD-ART manuscript, very explicitly elaborating Soekarno's ideas. But often in real terms, the political policies of PDIP, especially when there are still paradoxes in national and local executives. PSI, because the party was newly established, the researcher concluded that in the text of the AD-ART also very explicitly offered political ideas of social democracy (democratic socialism), although it still needed proof when in government. PKS, a party is undergoing a transparent ideological transformation, from a political background of Islamic Fundamentalism to Moderate Islam, where secular nationalism values also began to flourish in this party after the 2004 elections.
\end{abstract}

Keywords: Ideology, Political Parties, PDIP, Marhaenism, PKS, Islamic Fundamentalism, PSI, Democratic Socialism

\title{
PENDAHULUAN
}

Salah satu fenomena anomali di tengah konstelasi partai politik di dalam proses demokrasi yang telah berusia dua dasawarsa adalah kecenderungan krisis ideologi politik di partai politik. Membincangkan ideologi tentu tak lepas dari bagaimana bangunan sebuah ide dan narasi politik yang diserap dari nilai-nilai dan prinsip politik yang visioner dan filosofis (ontologi) dikembangkan melalui sistem dan metode yang konsisten (epistemologi) serta mampu menginternalisasinya menjadi pola dan tindakan politik dalam kehidupan masyarakat (aksiologi). Singkat kata, sejauh mana ideologi masih menjadi alat dan tujuan politik yang terbangun secara sistemik, terencana dan konsisten di seluruh elemen struktural dan fungsional partai politik. Realitasnya hal tersebut sukar untuk dibongkar secara terbuka 
sehingga masyarakat mampu mengidentifikasi secara nyata (Aminuddin, 2009). Partai politik, sebagai instrumen politik yang sangat strategis di dalam lanskap demokrasi patut menjadi subjek pertaruhan relevansi ideologi politik yang secara makro berkontribusi terhadap arah dan tujuan kehidupan politik bangsa dan negara..Partai politik mempunyai posisi (status) dan peranan (role) yang sangat penting dalam setiap sistem demokrasi. Partai memainkan peran penghubung yang sangat strategis antara proses-proses pemerintahan dengan warga negara. Karena itu, partai merupakan pilar yang sangat penting untuk diperkuat derajat pelembagaannya (the degree of institutionalization) dalam setiap sistem politik yang demokratis. Bahkan, oleh Schattscheider (Schattschneider, 1960) dikatakan pula, "Modern democracy is unthinkable save in terms of the parties".

Namun demikian, seiring rendahnya derajat ideologisasi partai, dapat dikatakan bahwa partai politik hari ini tidak lebih daripada kendaraan politik bagi sekelompok elite yang berkuasa atau berniat memuaskan 'nafsu birahi' kekuasaannya sendiri. Partai politik hanya lah berfungsi sebagai alat bagi segelintir orang yang kebetulan beruntung yang berhasil memenangkan suara rakyat yang mudah dikelabui, untuk memaksakan berlakunya kebijakankebijakan publik tertentu 'at the expense of the general will' atau kepentingan umum (Aulia, 2017).

Kehampaan ide, nilai dan identitas politik yang hakiki dan substansial mendegradasikan peranan dan fungsi partai politik menjadi komoditas politik kaum oligarki ekonomi maupun politik. Partai politik kehilangan bentuk dari wujud ekspresi ide-ide, nilai dan paradigma politik yang filosofis dan visioner. Hal itu tentu kontradiksi dengan upaya demokrasi dan sejarah kekayaan ideologi perpolitikan di Indonesia periode 1920-1966 (Castles \& Feith, 1970).

Artikel ini akan menjajaki perbedaan dan pengerucutan (convergence) ideologis, yakni dengan memeriksa persepsi para elit politik mengenai kecenderungan ideologis baik partai mereka sendiri maupun partai saingan. Selanjutnya, pendalaman secara kualitatif mengenai posisi (positioning) 
kepartaian di dalam konfigurasi politik, segmentasi konstituen politik dan visimisi dan kebijakan politiknya. Secara diskursus global, penelitian ini juga akan menjadi sebuah jawaban terhadap tesis bahwa ideologi telah mati seperti yang dikemukakan intelektual Amerika Daniel Bell di tahun 1970-an dan Francis Fukuyama dalam narasinya The End of History (Fukuyama, 2006) pasca runtuhnya komunisme Uni Soviet. Ataukah ideologi telah bertransformasi membentuk sebuah varian turunan atau baru.

Tabel. 1 Peta Ideologi Partai Politik Peserta Pemilu 2004

\begin{tabular}{|c|c|c|}
\hline No. & Ideologi & Partai Politik \\
\hline 01. & Islam & $\begin{array}{c}\text { Partai Bintang Reformasi, Partai Persatuan } \\
\text { Pembangunan, Partai Persatuan Nahdlatul Ummah } \\
\text { Indonesia, Partai Keadilan Sejahtera, Partai Bulan } \\
\text { Bintang, }\end{array}$ \\
\hline 02. & Nasionalis Religius & $\begin{array}{c}\text { Partai Kebangkitan Bangsa, Partai Amanat Nasional, } \\
\text { Partai Sarikat Indonesia, Partai Golkar, Partai Karya } \\
\text { Peduli Bangsa, Partai Keadilan dan Persatuan } \\
\text { Indonesia, Partai Patriot Pancasila, Partai Demokrat, } \\
\text { Partai Persatuan Daerah, Partai Merdeka, Partai } \\
\text { Indonesia Baru, Partai Persatuan Demokrasi } \\
\text { Kebangsaan. }\end{array}$ \\
\hline 03. & Nasionalis Sekuler & $\begin{array}{c}\text { PDI-P, PNBK, Partai Pelopor, PNI Marhaenisme, } \\
\text { Partai Penegak Demokrasi Indonesia, Partai Buruh } \\
\text { Sosial Demokrat. }\end{array}$ \\
\hline 04. & Kristen & Partai Damai Sejahtera \\
\hline
\end{tabular}

Sumber : Jurnal Asep Nurjaman (Nurjaman, 2016)

Berdasarkan tabel diatas ada beberapa ideologi partai politik yang sudah umum di Indonesia disini Peneliti akan membedah ideologi-ideologi mainstream yaitu nasionalis, agama dan sosialis. Atas dasar tersebut, maka partai politik yang dianggap merepresentasikan adalah Partai Demokrasi Indonesia Perjuangan (PDIP), Partai Keadilan Sejahtera (PKS) dan Partai Solidaritas Indonesia (PSI). Asumsinya, partai politik di atas memiliki keragaman ide politik yang khas, yaitu PDIP dengan ide nasionalismarhaenisme, PKS dengan politik Islam dan PSI dengan ide sosialisme demokrasi.

\section{METODE PENELITIAN}

Metode penelitian menggunakan deskriptif-kualitatif yaitu merupakan proses penafsiran atau pembahasaan dan pewacanaan realitas sebagai sebuah narasi dari konstruksi sosial. Proses-proses penelitian kualitatif ini dilakukan 
dengan berbagai bentuk dan metode, baik dengan menggunakan wawancara secara mendalam (in-depth interview) dan menempatkan pihak yang diwawancara sebagai subjek penelitian atau informan yang memiliki pengetahuan (knowledge) dan kemudian hasil dari penelitian ini berbentuk narasi ataupun deskripsi (narration and thick description) yang menggambarkan dan menjelaskan realita dari sudut pandang yang sesungguhnya ketika peneliti telah melebur dan mendalami subjek penelitiannya (getting in, getting along, getting out).

\section{TEMUAN DAN PEMBAHASAN}

\section{Partai politik dan ideologi}

Indonesia merupakan negara yang menganut sistem politik demokrasi yaitu dengan kesepakatan bersama untuk mendapatkan suatu keputusan sejak indonesia merdeka pada tanggal 17 agustus 1945 founding father indonesia sudah mulai merencanakan untuk melakukan pemilu agar terciptanya kondisi politik yang adil dan baik di Negara Indonesia, pada tahun 1955 adalah kali pertama bangsa indonesia melakukan pemilu yang mana menunjukkan bangsa indonesia sudah menuju jalan yang benar dalam proses demokrasi,berikut nama partai dan ideologi partai yang ada dari pertama kali proses demokrasi di indonesia dilaksanakan.

Tabel 2. Nama Partai Politik dan Asas Partai

\begin{tabular}{|l|l|}
\hline Ideologi/Azas Partai & Partai \\
\hline Pancasila & Partai Indonesia Baru, Partai Kristen \\
& Indonesia, PNI Supeni, Partai Aliansi \\
& Demokrasi, PDI Perjuangan, Partai Abul \\
& Yatama, Partai Kebangkitan Merdeka, Partai \\
& Demokrasi kasih Bangsa, Partai Amanat \\
& Nasional, Partai Katolik Demokrat, Partai \\
& Pilihan Rakyat, Partai Rakyat Indonesia, \\
& Partai Solidaritas Pekerja, PNI PRON \\
& MARHAENIS, Partai Ikatan Pendukung \\
& Kemerdekaan Indonesia, Partai REPUBLIK, \\
& Partai Islam Demokrat, Partai Demokrasi \\
Indonesia, Partai GOLKAR, Partai \\
Kebangkitan Bangsa, Partai Buruh, \\
Nasional, Partai MKGR, Partai Daulat \\
Rakyat, Partai Cinta Damai, Partai Keadilan \\
dan Persatuan, Partai Keadilan dan \\
Persatuan, Partai Solidaritas pekerja \\
Seluruh Indonesia, Partai Nasional Bangsa \\
\hline
\end{tabular}




\begin{tabular}{|l|l|}
\hline & $\begin{array}{l}\text { Indonesia, Partai Bhineka Tunggal Ika, } \\
\text { Partai Solidaritas Uni Nasional Indonesia, } \\
\text { Partai Nasional Demokrat, Partai Ummat }\end{array}$ \\
& $\begin{array}{l}\text { Muslimin Indonesia, Partai Pekerja } \\
\text { Indonesia, Partai Hati Nurani Rakyat, Partai } \\
\text { Gerindra, Partai Demokrat, Partai Nasdem, } \\
\text { dan Partai PSI }\end{array}$ \\
\hline Islam & $\begin{array}{l}\text { Partai Kebangkitan Muslimin Indonesia , } \\
\text { Partai Umat Islam, Partai Masyumi Baru, } \\
\text { Partai Persatuan Pembangunan, Partai } \\
\text { Syarikat Islam Indonesia, Partai Syarikat } \\
\text { Islam Indonesia, Partai Keadilan } \\
\text { Sejahtera, Partai Partai Politik Islam } \\
\text { Indonesia MASYUMI, Partai Bulan Bintang, } \\
\text { Partai Keadilan, Partai Persatuan, dan Partai } \\
\text { bulan Bintang }\end{array}$ \\
\hline Pancasila dan akidah Islam & $\begin{array}{l}\text { Partai Kebangkitan Umat, Partai Nahdatul } \\
\text { Umat }\end{array}$ \\
\hline Sosial Demokrasi Kerakyatan & Partai Rakyat Demokratik \\
\hline Demokrasi Religius & Partai Uni Demokrasi Indonesia \\
\hline
\end{tabular}

Sumber: Jawa Pos, Selasa 25 September 2007 dan diolah peneliti 2019

Dari tabel di atas dapat diambil kesimpulan sejak berdirinya Indonesia sudah banyak partai - partai yang mendirikan organisasinya dengan menggunakan ideologi Pancasila dan ada beberapa yang menggunakan ideologi islam serta gabungan dari kedua ideologi tersebut.

\section{Ideologi Marhaenisme dan Partai Demokrasi Indonesia Perjuangan (PDIP)}

Marhaenisme adalah jatidiri dari ide, narasi dan laku politik Soekarno. Telah dijelaskan di depan, bahwa konsep marhaenisme sebagai interpretasi terhadap personifikasi rakyat kecil yang memiliki sebidang tanah kemudian menggarap sendiri, alatnya punya dia sendiri dan hasilnya cukup untuk kebutuhan keluarganya. Kedua, marhaenisme diambil dari teori dialektika yang dikembangkan oleh Hegel dan didukung oleh Karl Marx dan F. Engels. Maka analisa marxisme menjadi pintu masuk untuk membedah lebih dalam marhaenisme Soekarno. PDIP dianggap sebagai partai politik yang memiliki keterikatan dan keterkaitan yang kuat dengan ideologi marhaenisme (Kurniasih, 2019). Hal ini ditarik dari sejarah PDIP sebagai estafet politik dari PDI (Partai Demokrasi Indonesia). faktor genealogi biologis Soekarno. Secara kepartaian politik, memang ada tiga trah Soekarno di dalam partai politik, 
yaitu Sukmawati Soekarnoputri yang pernah menjadi ketua umum PNIMarhaenisme, Rachmawati Soekarnoputri yang pernah bergabung di Partai Pelopor, Partai Nasdem dan terakhir sebagai wakil ketua umum di Partai Gerindra serta Megawati Soekarnoputri yang menjadi ikon PDI dan PDIP.

PDIP menemui momentumnya ketika orde baru pemerintahan Soeharto lengser pada tahun 1998. Sebagai partai yang memiliki sejarah politik nasionalisme dan personifikasi politik Soekarno, maka keikutsertaan PDIP di dalam setiap pemilu di era demokrasi mulai tahun 1999-2019 menjadi partai yang memiliki basis dan sistem kekuatan politik yang telah mapan. Hasil pemilu legislatif PDIP sebagai berikut. Di pemilu tahun 1999, PDIP menjadi partai pemenang dengan meraih suara $35.689 .073(33,74 \%)$ dengan jumlah kursi 153 (33,12\%). Pemilu 2004 PDIP meraih suara 21.026.629 (18,53\%) dengan jumlah kursi 109 (19,82\%), yang menempatkan pada posisi kedua. Pemilu 2009 PDIP meraih suara 14.600.091 (14,03\%) dengan jumlah kursi 95 (16,96\%). Pemilu 2014, PDIP untuk kali kedua, berhasil menempatkan kadernya menjadi presiden RI, dengan meraih suara pileg sejumlah 23.681.471 (18,95\%) dengan jumlah kursi 109 (19,46\%). Artinya masyarakat dengan mudah mengidentifikasi bahwa PDIP adalah partai nasionalistik yang memiliki wacana politik kebangsaan, kerakyatan dan keadilan sosial. Bab II Pasal 5 yang berbunyi Jatidiri Partai adalah kebangsaan, kerakyatan dan keadilan sosial yang termaktub dalam Anggaran Dasar Partai Demokrasi Indonesia Perjuangan Tahun 2015-2020.

Peneliti kemudian mengkonfirmasi kepada Bapak Yordan, selaku wakil sekretaris DPD PDIP Jawa Timur, terkait korelasi ide-ide politik Soekarno (Marhaenisme) di dalam narasi dan kebijakan politik PDIP.

\footnotetext{
"Ide dasar politik PDIP ada dua hal. Pertama. nasionalis, mengikuti dari ide Bung Karno. Indonesia ini untuk semua, tidak boleh satu etnis suku agama kelompok masyarakat terabaikan atau terdiskriminasi. Jadi sesuai AD ART ideologi PDIP itu Pancasila. Karena banyak tafsir Pancasila, Pancasila yang mana? Yaitu Pancasila pada saat pidato Bung Karno tanggal 1 Juni 1945. Kedua, dari sisi ekonomi, kita ingin ekonomi kerakyatan. Kita tidak ingin satu rakyat pun mengalami kesusahan. Kita ingin kesejahteraan sosial atau dalam bahasa Pancasila yaitu keadilan sosial. Jadi ide-ide khas Bung Karno yaitu nasionalisme dan demokrasi ekonomi".
} 
POLITICON : Jurnal Ilmu Politik Vol.1 No.2 ; Hal 135-157

Website : http://journal.uinsgd.ac.id/index.php/politicon ISSN : 2685-6670 ( Online )

Kemudian merujuk pada Anggaran Dasar dan Anggaran Rumah Tangga (AD dan ART) Partai Demokrasi Indonesia Perjuangan hasil Kongres PDIP tahun 2015-2020, yang berbunyi sebagai berikut ;

a. Alat perjuangan guna membentuk dan membangun karakter bangsa berdasarkan pancasila 1 juni 1945;

b. Alat perjuangan untuk melahirkan kehidupan berbangsa dan bernegara yang ber-ketuhanan, memiliki semangat sosio nasionalisme, dan sosio demokrasi (tri sila);

c. Alat perjuangan untuk menentang segala bentuk individualisme dan untuk menghidupkan jiwa dan semangat gotong royong dalam kehidupan bermasyarakat, berbangsa dan bernegara (eka sila) (PDIP, 2015).

Lalu mengenai korelasi ide-ide politik Soekarno di dalam narasi politik

PDIP, peneliti memperoleh tanggapan bahwa ajaran-ajaran Bung Karno seperti Trisakti yang menjadi landasan PDIP.

"atas dasar ajaran Bung Karno, untuk itu kita mendukung sepenuhnya pemerataan kesejahteraan di seluruh Indonesia. Bahkan di dalam AD-ART kita, kita lebih menegaskan kembali bahwa salah satu tugas partai adalah mewarisi ajaran-ajaran Bung Karno, secara eksplisit. Itu yang tidak tertuang di dalam $A D$ ART sebelumnya".

Peneliti mengkorelasikan asumsi tersebut dengan teks AD ART PDIP, yang memang ditemukan beberapa hal, yaitu pada Bab III Pasal 9 huruf c yang berbunyi

"Membentuk Kader Partai Yang Berjiwa Pelopor, Dan Memiliki Pemahaman, Kemampuan Menjabarkan Dan Melaksanakan Ajaran Bung Karno Dalam Kehidupan Bermasyarakat, Berbangsa, Dan Bernegara."

Kemudian Bagian Keempat Pasal 10 huruf c yang berbunyi “menjabarkan, menyebarluaskan dan membumikan ajaran Bung Karno dalam kehidupan bermasyarakat, berbangsa, dan bernegara;" Huruf d yang berbunyi "menghimpun dan memperjuangkan aspirasi rakyat berdasarkan ideologi Pancasila 1 Juni 1945 dan Undang Undang Dasar Negara Republik Indonesia 1945, serta jalan TRISAKTI sebagai pedoman strategi dan tujuan kebijakan politik Partai". Huruf g yang berbunyi, mempengaruhi dan mengawasi jalannya penyelenggaraan negara agar senantiasa berdasarkan pada ideologi Pancasila 1 Juni 1945 dan Undang Undang Dasar Negara Republik Indonesia 1945, serta jalan TRISAKTI sebagai pedoman strategi dan tujuan kebijakan politik Partai demi terwujudnya pemerintahan yang kuat, efektif, bersih dan berwibawa;" Serta secara eksplisit tugas dan fungsi partai di Bab VII Pasal 86 
huruf a yang berbunyi "menanamkan dan menyebarluaskan ajaran Bung Karno;"

Untuk mempertegas ajaran-ajaran Soekarno agar menjadi ide dasar politik PDIP, terutama dalam membangun pola kaderisasi telah diatur dalam Anggaran Rumah Tangga Bab IV Pasal 83 (PDIP, 2015). Secara tekstual, PDIP memang memiliki garis ideologi yang tegas. Pancasila sebagai ideologi politik PDIP adalah pidato Soekarno 1 Juni 1945. Pancasila yang bermatra pada sosionasionalisme, sosio-demokrasi dan ketuhanan yang berkebudayaan. Marhaenisme sebagai prinsip politik Soekarno pun menjadi materi yang diberikan ke seluruh kader PDIP. Artinya, prinsip-prinsip marhaenisme yang bertitik tolak pada analisa marxist sebagai pandangan kritis terhadap ketimpangan sosial-ekonomi masyarakat akibat ekonomi politik liberaliskapitalisme pun seharusnya menjadi pedoman politik PDIP. Karena sebagai antithesis dari liberalis-kapitalisme maka, kedudukan Marhaenisme adalah inheren dengan sosialisme. Gambaran marhaenisme secara jelas dan tegas disampaikan dalam tulisan Soekarno.

"Seorang Marhaen adalah orang yang mempunyai alat produksi yang sedikit. Bangsa kita yang puluhan jiwa jumlahnya, sudah di melaratkan, bekerja bukan untuk orang lain dan tidak ada orang bekerja untuk dia. Marhaenisme adalah sosialisme Indonesia dalam praktik (Soekarno, 1923)".

Meskipun telah tertera jelas arah dan pandangan ide politik PDIP, namun realitas politik PDIP di beberapa momen memang menimbulkan kontroversial. Salah satunya Presiden Megawati melakukan privatisasi terhadap BUMN dengan menjual Indosat di tahun 2003. Lalu kebijakan pemberlakuan alih daya (outsorcing) tenaga kerja di perusahaan berdasarkan UU 13 tahun 2003 tentang Ketenagakerjaan, yang dianggap menciptakan kelas sosial buruh permanen No.Kep.101/Men/VI/2004 Tahun 2004 tentang Tata Cara Perijinan Perusahaan Penyedia Jasa Pekerja/Buruh (Kepmen 101/2004).

Di awal periode pemerintahan Jokowi di tahun 2014 sudah memunculkan kebijakan untuk mengalihkan subsidi BBM ke pembangunan infrastruktur. Kebijakan ini menjadi semacam episode drama politik yang membuat keresahan di tengah masyarakat. Selain 
soal kenaikkan BBM akan linear dengan kenaikan harga-harga bahan pokok masyarakat, kebijakan pemerintah terkait ini pun berjalan fluktuatif.

Kebijakan pemerintahan Jokowi lain yang paradoks dengan ide-ide politik Marhaenisme Soekarno adalah pembiaran pembangunan pabrik semen di pegunungan kendang di Kabupaten Rembang, Jawa Tengah di tahun 2017. Ganjar Pranowo, yang juga sebagai kader PDIP dan Gubernur Provinsi Jawa Tengah pun tidak mengambil langkah populis yang pro-rakyat.

kebijakan pemerintah untuk hutang demi pembangunan infrastruktur dan sumber daya manusia menjadi kritik oleh berbagai kalangan (Kusuma, 2019). Jokowi pernah mengatakan kebijakan yang sengaja menggenjot pembangunan infrastruktur dilakukan karena Indonesia sudah ketinggalan jauh dari negara-negara tetangga dalam hal penyediaan infrastruktur dasar. Selain itu, infrastruktur merupakan kunci untuk bisa mendorong pertumbuhan industri hingga ekonomi nasional. Sementara dari sisi pelayanan, pemerintah juga perlu menambah jumlah anggaran pos ini, misalnya untuk kebutuhan pendidikan dan kesehatan. Data mencatat, memang jumlah anggaran kedua pos itu naik cukup signifikan di era Jokowi (Shelmi, 2019). Jika dipertautkan dengan gagasan politik Soekarno, utamanya dalam konsep politik Berdikari Pada tahun 1963, Sukarno menyerukan kebijakan ekonomi yang tertuang dalam Dekon (Deklarasi Ekonomi). Di dalamnya, Sukarno sedikit berkompromi terhadap asing dan pihak swasta. Modal asing boleh masuk, tapi sharing. 60\% untuk Indonesia, dan 40\% untuk asing, ditambah setelah 20 tahun akan menjadi milik Indonesia sepenuhnya, tentu kebijakan hutang bukan menjadi kebijakan yang sepenuhnya tepat. Namun peneliti mengamati memang persoalan negara hari ini sangat kompleks. Persoalan hari ini adalah episode dari kebijakan pemerintah sebelumnya. Ketertinggalan di dalam pembangunan infrastruktur menjadi alasan fundamental yang harus segera diselesaikan, sedangkan di sisi lain anggaran negara yang terbatas harus pula segera diputuskan melalui skema 
alternatif. Untuk menjawab persoalan tersebut, pemerintah selalu menegaskan kebijakan hutang yang diambil masih dalam batas kewajaran, utamanya sekali lagi, untuk kepentingan pembangunan sarana public (Kemenkeu, 2019).

\section{Ideologi Sosialisme Demokrat dan Partai Solidaritas Indonesia (PSI)}

PSI adalah partai yang terlahir pada tanggal 16 November 2014. Partai ini secara tegas memiliki ide politik solidaritas (komunalisme), kesetaraan dan keadilan sosial, dengan membawa barisan pemuda (kaum milenial) sebagai lokomotif perjuangan ide-ide politik tersebut.

Ada beberapa poin penting dalam menelaah PSI yang kaitannya dengan gerakan sosialisme internasional, Sosialisme Internasional merupakan asosiasi partai politik di seluruh dunia, yang sebagian besar berusaha untuk membangun sosialisme demokratis. Sebagian besar mereka terdiri dari partai sosialis demokrat, partai demokratik sosial dan partai buruh.

Dibentuk tahun 1951 sebagai penerus Partai Buruh, Sosialis Internasional (SI), namun pada awal abad kesembilan belas, ia memiliki anteseden sampai akhir abad kesembilan belas. Asosiasi ini telah berkembang menjadi 153 anggota partai dari lebih 100 negara. Anggotanya telah memerintah di banyak negara termasuk sebagian besar Eropa. Partai Sosialis Eropa (PES), sebuah partai politik besar Eropa, merupakan organisasi yang terkait dengan SI . Pertama, partai yang memiliki simbol bunga mawar merah yang digenggam erat ini mengingatkan pada lambang gerakan Sosialisme Internasional. Seperti yang dikutip melalui salah satu laman berita online.

\footnotetext{
"Diskurus tentang simbol sesungguhnya ada hal menarik untuk dibahas. Munculnya partai baru bernama Partai Solidaritas Indonesia (PSI) cukup menghentakkan publik Indonesia.Pasalnya lambang yang digunakan PSI ini persis dengan lambang gerakan Sosialis Internasional. Yakni sama-sama menggunakan simbol tangan terkepal menggenggam bunga mawar. Bedanya, Sosialis Internasional ada daunnya, sementara PSI tak memakai daun.Namun bila dicermati dari corak penggunaan embel-embel seperti Sis (untuk panggilan perempuan) Bro (untuk panggilan laki-laki) di lingkaran PSI seperti dilansir dari laman resminya, jelas ini khas dan kental dengan gaya-gaya sosialis. Sebuah gaya sapaan egaliter tentang kesetaraan. Sama rata sama rasa. Tak ada kelas, bahwa semua setara. Kalau dulu misalnya untuk laki-laki sapaan egaliter yang populer adalah 'Boeng' atau 'Bung (NUSANTARANEWS.CO, 2019)'.
} 
POLITICON : Jurnal Ilmu Politik Vol.1 No.2 ; Hal 135-157

Website : http://journal.uinsgd.ac.id/index.php/politicon ISSN : 2685-6670 ( Online )

Kedua, sebutan bro dan sis di kalangan internal PSI yang menunjukkan adanya relasi yang egaliter dan kesetaraan antar kader, adalah sangat khas dengan prinsip-prinsip dasar relasi komunalistik sosialisme (Yesicha, 2019).

Ketiga, secara ide dasar politik PSI yang mengusung politik solidaritas, kesetaraan, inklusivitas dan keadilan sosial adalah inheren dengan nilai-nilai politik sosialisme demokrasi. Dan PSI yang terlahir pada era demokrasi liberal jilid II ini mengingatkan pada PSI (Partai Sosialis Indonesia) yang didirikan oleh Sutan Syahrir pada tanggal 12 Februari 1948, bukan hanya kesamaan akronim namun juga landasan politiknya.

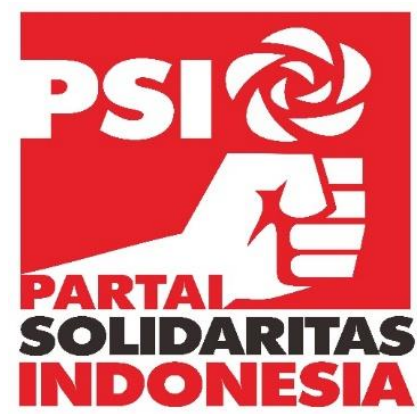

Gambar 1. Lambang PSI

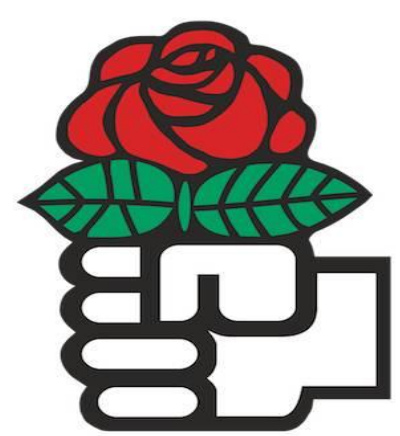

Gambar 2. Logo Gerakan Sosialisme Internasional

Terkait kesamaan simbol antara PSI dengan gerakan sosialisme internasional, melalui situs resmi PSI menjelaskan bahwa tidak ada keterkaitan yang kuat dengan gerakan sosialisme internasional.

"Bunga mawar tidak mempropagandakan harum semerbaknya. Dengan sendirinya harum semerbaknya itu tersebar di sekelilingnya".. Kalimat diatas diucapkan oleh Presiden Pertama Indonesia, Soekarno pada pidatonya tanggal 29 Juli 1959 di Semarang. Dari sepenggal kalimat tersebutlah yang kemudian 
menjadi inspirasi kami untuk mewujudkannya menjadi logo Partai Solidaritas Indonesia (PSI) (Psi.id, 2016)".

Bantahan terhadap kesamaan dengan logo sosialisme internasional maupun sejarah Partai Sosialis Indonesia juga dilontarkan oleh sekretaris DPW PSI Jawa Timur. Namun ketika ditanya mengenai ideologi politik di PSI, Afif menyetujui bahwa partai-partai politik hari ini memang tidak setajam era demokrasi liberal 1950-an. Artinya ide-ide politik hampir sama, mencair dan bisa melebur antar partai politik. Baginya, yang membedakan adalah kebaruan PSI dalam merekrut anak-anak muda yang bebas dari beban politik masa lalu, baik secara struktural maupun kultural. Kedua, anak-anak muda tersebut diberi kesempatan untuk tampil menjadi elit politik.

Menariknya, di dalam kesempatan wawancara itu juga, ketika peneliti mengkritisi partai politik pasca reformasi dan terutama partai-partai baru yang tidak mampu menampilkan keberagaman ide politik yang menyebabkan masyarakat susah untuk mengidentifikasi, hal ini jelas anomali bagi peradaban demokrasi, secara spontan Afif menyebutkan contoh-contoh partai politik lain.

"sekarang itu kita tidak bisa memetakan ini partai kiri ini partai kanan. Karena
apa, oke salah satunya, boleh ya sebut nama. Anggap saja kita lihat PKS, pks ini
yang dulu awalnya sebagai partai agamis, yang orang bilang partai kanan. Tapi,
waktu berjalan terus menerus akhirnya partai ini tidak berani menampilkan diri
sebagai partai kanan, akhirnya mencoba menjadi partai tengah untuk bisa
merangkul orang banyak. Lalu PDIP, yang katanya partai nasionalis. Dan hari ini
partai ini juga mengarah ke tengah. Justru hari ini, partai-partai yang agamis
dipegang seperti Gerindra dan PAN, karena mereka mengetahui ada lahan yang
subur yang bisa di gali".
waban di atas memang menunjukkan realitas politik kontemporer. Terutama ketika Pilpres 2019, dimana terbentuk dikotomi konfigurasi partai politik antara isu Nasionalis dan Islamis. Isu Nasionalis adalah kubu PDIP, Golkar, Nasdem, PPP, Hanura, PKB, PKPI, Perindo dan PSI sedangkan isu Islamis di kendalikan oleh Partai Gerindra, PAN, PKS dan Demokrat. Kondisi demikian di dalam perspektif ide dasar yang kepartaian terbentuk baik secara struktural (legal-formal) maupun kultural (basis massa) bisa disimpulkan terjadi revolusi politik.

Partai-partai politik di era demokrasi jilid II (1998 - ....) memang memang mengalami anomali. Kuantitas partai politik yang ada tidak 
berkorelasi dengan banyaknya ide-ide politik yang berbeda. Maka tidak ada dialektika politik. Hal ini jelas membedakan dengan ideologi kepartaian di Inggris, Amerika, Australia dan Eropa Berat, karena justru partai-partai politik yang ada berupaya untuk saling bersekutu yang selanjutnya hanya sebagai kendaraan politik yang bersifat pragmatis. Hal di atas diperkuat dengan tanggapan dari Afif, selaku salah satu pejabat struktural di DPW PSI Jawa Timur.

Secara umum, Afif menegaskan bahwa ideologi adalah nasionalisme. Ideologi (atau DNA-dalam bahasa PSI) Nasionalisme yang menitikberatkan pada anti korupsi dan anti-intoleran. Anti korupsi diterjemahkan ke dalam struktur kepengurusan yang benar-benar baru, yang berarti tidak pernah terlibat di dalam partai politik sebelumnya serta penentuan caleg yang tidak pernah terlibat dalam tindakan korupsi dan diseleksi oleh kalangan independen, bukan dari internal kepengurusan PSI. Lalu, setelah caleg terpilih akan dikontrol kinerjanya, terutama di dalam gedung legislatif oleh PSI melalui CCTV. Ke depan, akan ada aplikasi PSI yang mampu diakses oleh masyarakat luas untuk turut terlibat dalam menilai kinerja legislator PSI.

Di kesempatan yang berbeda, peneliti sempat mengkonfirmasi terkait dinamika ideologi kepartaian di era demokrasi kepada Syafrudin, S.IP, politisi PSI, yang juga caleg PSI dari wilayah Dapil XIV Jawa Timur. Menurutnya, bahwa partai politik yang ada sekarang adalah irisan-irisan dari partai politik yang telah ada sebelumnya.

“ Seperti Partai Berkarya yang merupakan irisan dari Partai Golkar. Gerindra, Hanura juga dari Partai Golkar dan lain-lain. Ada Partai Garuda yang juga banyak diisi anak muda. Sedangkan yang membedakan dengan PSI adalah embrionya, menurut saya.. Yaitu para pendiri PSI yang mayoritas sebagai intelektualintelektual muda (The Indonesia Institute), ada Jeffrie Geovanie, Endang Tirtana, Andi Syaiful Haq. Dan mereka juga bagian dari SMRC. Mereka intelek politik. Mereka ingin membangun ideologi baru sebenarnya, yaitu keterbukaan”.

Lantas, bagaimana tipologi ideologi politik PSI, jika dikategorikan ke dalam sosialisme, liberalisme, sosialisme demokrasi. Syafrudin, secara tegas menyatakan bahwa PSI adalah liberal. 
“ sebenarnya PSI ini adalah antitesa dari partai yang lama. Maka, PSI diisi oleh orang-orang baru, jargon baru dan lain-lain. Ideologinya adalah keterbukaan. Nasionalis-liberal dengan azaznya Pancasila, yang terbuka bagi semua pihak.

Untuk menakar lebih dalam ideologi PSI, peneliti menganalisa teks anggaran dasar (AD) dan anggaran rumah tangga (ART) (PSI, 2016) yang secara tegas memang merujuk pada ide-ide sosialisme demokrasi (the welfare state). Hal ini kemudian di konfirmasi oleh Syafrudin.

“ memang liberal kan ada variannya. Liberal kan nasionalis ya, nasionalisnya dia nasionalis modern. Bahwa pandangannya mereka punya harapan membangun negara ini adalah dengan nilai-nilai kesejahteraan, itu kan juga tertuang di dalam Pancasila sila ke lima. PSI mengambil ruang itu sebagai jargon kerakyatan. Kenapa negara kesejahteraan, karena peran negara memfasilitasi saja, tidak terlibat langsung di dalam bisnis. Kan ketahuan misalnya PSI pro terhadap reklamasi, gak masalah investasi sebanyak-banyaknya, tapi negara memfasilitasi. Tapi dari hasil itu APBN dikembalikan lagi ke rakyat. Itu jalan ketiga. Saya yakin semua partai berpandangan seperti itu. Dia konteksnya sosdem, tapi dia tidak sosialisme demokrasi kerakyatan (sosdemkra), artinya mengorganisasi rakyat. PSI tidak bisa hitam putih meneruskan PSI jaman Sutan Syahrir".

Ketika peneliti mengkonfirmasi lebih dalam, Syafrudin menilai pasca reformasi partai yang ada belum mampu menyelesaikan masalah. Lalu perlu membangun sistem yang baru, berkaitan dengan nilai-nilai, ideologi politik yaitu memunculkan semangat anak muda. Secara ideologi, Syafrudin merekonfirmasi bahwa ideologi PSI adalah sosial demokrat.

Untuk simbol bunga, menurut Syafrudin, hak itu memiliki makna demokrasi, solidaritas. Lalu menjelaskan pula bahwa simbol bunga di Amerika dan Eropa jaman dahulu adalah bermakna perlawanan, pembebasan.

"Jadi, saya lihat bukan sosialis, tapi sosialisme demokrat. Ini the new political party di era demokrasi liberal, di era keterbukaan".

Namun ketika peneliti mengkaitkan salah satu kebijakan pemerintah yang dianggap pro-liberal yaitu pembangunan jalan tol yang berakibat pada penggusuran tanah warga, Syafrudin menanggapi bahwa kasus penggusuran tanah harus tetap dilihat secara berimbang.

"kan negara mengatur. Kalau kompensasinya jelas kan gak papa, seimbanglah. Kan itu juga ada peraturan perundang-undangnya. Tanpa PSI pun itu negara akan melakukan itu, yang penting kan ada kepastian hukum, jangan sampai terombang-ambing".

Peneliti mengkaitkan kembali dengan teks di dalam AD-ART PSI yang secara eksplisit mencantumkan narasi dan ide-ide politik sosialisme demokrasi atau demokrasi sosial. Di dalam teks tersebut terdapat beberapa 
konsep yang berkelindan dengan ide-ide politik sosialisme demokrasi seperti yang ada di dalam Anggaran Dasar Bab III Pasal 8 yaitu mewujudkan negara kesejahteraan, memenuhi hak asasi manusia, menciptakan tatanan ekonomi dengan prinsip demokrasi ekonomi, menegakkan keadilan sosial, menegakkan kehidupan sosial budaya yang egaliter.

Sosialisme demokrasi adalah antitesis dari demokrasi libertarian (liberal-kapitalisme). Pintu masuk dalam implementasi sosialisme demokrasi adalah pengakuan dan penghormatan terhadap hak asasi manusia, seperti yang termaktub dalam Konvensi Hak-Hak Dasar PBB tahun 1996 (United Nation's Convenants On Basic Rights 1996) yang menyatakan lima sendi hak asasi yaitu hak-hak sipil, politik, sosial, ekonomi dan budaya. Gagasan dibalik lima dimensi konsep hak-hak asasi tersebut adalah kebebasan dan kesempatan bagi pengembangan personal dan partisipasi penuh dari semua individu dalam kehidupan sosial haruslah dijamin bagi semua manusia terlepas dari status sosial dan kekayaannya.

pertama-tama negara memiliki kewajiban untuk mencegah risiko tersebut untuk terjadi. Bila negara tidak mampu melakukannya, maka negara harus memberikan kompensasi kepada "pihak-pihak yang dirugikan" sebagai konsekuensi atas risiko yang mereka alami. Namun semua warga negara juga wajib untuk berkontribusi apapun yang dapat mereka lakukan guna mencegah atau mengganti resiko dengan usaha mereka sendiri. Dengan demikian, demokrasi sosial adalah mengenai kewarganegaraan sosial (Marshall \& Bottomore, 1992). Secara sosio-historis berdirinya Negara Kesatuan Republik Indonesia baik melalui perundingan di BPUPKI sampai pada pengesahan Pancasila sebagai dasar negara dan UUD 1945 sebagai konstitusi pada sidang I PPKI, menyertakan secara tegas bahwa kewarganegaraan atas pelayanan sosial telah dijamin oleh konstitusi. Pancasila sila ke dua dan lima. UUD 1945 Pasal 33 dan 34.

Berkaca dari gagasan konseptual di atas, demokrasi sosial seharusnya sudah dikenal cukup baik di Indonesia. Nilai-nilai dasar yang terdapat di dalam 
Pembukaan dan Batang Tubuh UUD 1945 mengakui dan menyatakan hal tersebut. Di banyak pertemuan dan diskusi para ilmuwan sosial politik dan aktivis sering kali perdebatan mengenai apa itu demokrasi sosial dan demokrasi libertarian diikuti dengan antusias, tetapi sayangnya karena pengalaman sejarah, banyak orang masih mencurigai istilah "sosial" dalam demokrasi sosial, sering dikaitkan dengan ideologi komunisme.

\section{Menakar Ideologi PKS}

Salah satu partai yang menarik untuk diteliti adalah dinamika kepartaian PKS. Berangkat dari gerakan tarbiyah yang memiliki sosio-historis dengan ide dan pemikiran Mohammad Natsir dan gerakan transnasionalisme Ikhawanul Muslimin, PKS berhasil menggabungkan dua sifat dan karakter organisasi yang sangat berbeda yaitu antara sebuah gerakan sosial dan partai politik. Namun dengan ketidakbiasaan itu kemudian ternyata PKS dapat membukukan performa elektoral yang bagus selama tiga kali pemilu berturutturut dari tahun 1999-2019 (Basyir, 2017).

Pengamatan peneliti di internal organisasi PKS, baik melalui studi literasi maupun dokumentasi di berbagai media terkait sikap politik PKS di dalam pemilu, telah terjadi tranformasi nilai-nilai yang sifatnya ideologis menjadi pragmatis, kalaupun bisa dijelaskan secara mendalam, terjadi faksional nilai dan ide politik. Transformasi fundamentalisme Islam menuju moderatisasi Islam menujukkan dikotomi ide dan nilai antara kedua varian tersebut.

Pertama, tidak semua kalangan muslim menerima demokrasi dan multi-partai untuk mengekspresikan nilai-nilai Islam dalam mengelola negara (Furkon, 2004), Kedua,Doktrin "sirriyah al-tanzim wa alamiyyah al-dakwah (Furkon, 2004), Ketiga, kontradiksi antara daya kritis para kader di satu sisi, dengan sistem kaderisasi yang mengedepankan ketaatan di sisi lain (Furkon, 2004), Keempat, informasi awal yang dimiliki peneliti menunjukkan, para aktor kunci di PKS menyadari bahwa kemampuan mereka mewarnai PKS tergantung dari posisi objektif mereka dalam ranah yang ditentukan oleh 
seberapa banyak dan berbobot modal yang berhasil diakumulasikan.

Salah satu momentum transisi yang secara formal berlangsung pada musyawarah kerja nasional di Hotel Inna Grand Beach, Sanur, Denpasar, Bali, pada 1 Februari 2008. Sebagian elite partai mendeklarasikan PKS sebagai partai terbuka, yang berarti PKS akan menerima calon non-Muslim bertanding di dalam pemilu 2009. Untuk pemilu 2009, caleg non-muslim akan diproyeksikan di lima daerah di wilayah tengah dan timur Indonesia yaitu Maluku, Maluku Utara, Papua, Papua Barat, dan Bali. Pemilu 2014, caleg nonMuslim banyak diusung PKS untuk daerah pemilihan Indonesia Timur, seperti Sulawesi Utara, Sulawesi Tengah, Sulawesi Barat, Papua, dan Papua Barat. Sedangkan pemilu 2019, salah satunya Jonias Latekay, SH putra asal negeri Elpaputih, Kecamatan Elapaputih Kapupaten Seram Bagian Barat (SBB) ini menjadi satu-satunya Calon Legislatif (Caleg) dari non muslim yang mendaftarkan diri ikut dalam Pemilihan Legislatif (Pileg) 2019 dari Partai Keadilan Sejahtera (PKS), Kebijakan ini memicu konflik internal antara kalangan petinggi partai. Ketua Dewan Syariah Pusat, Surahman Hidayat menyatakan mendukung langkah tersebut (Novi, 2013). Keputusan ini ditentang habis-habisan oleh salah satu pendiri PK, Yusuf Supendi. Ia menuding Ketua Majelis Syura, Hilmi Aminuddin, dan sekretaris jenderal saat itu, Anis Matta (sekarang presiden) sebagai kalangan yang menginginkan PKS sebagai sebuah partai terbuka.

Meskipun memang secara pemikiran politik, PKS menolak pemisahan agama dan negara (sekularisme) di Indonesia. Sekularisme dianggap tidak relevan, karena Indonesia adalah negara yang mengakui tauhid, Ketuhanan Yang Maha Esa. Jadi, menurut PKS, Indonesia adalah NKRI yang Berketuhanan Yang Maha Esa. Secara formal kepartaian, PKS berusaha menyesuaikan diri dengan norma kehidupan tata negara, tetapi simbol-simbol nasionalisme (Pancasila, UUD 1945) tidak tampak dalam platform.

Di sisi lain, ada faksional antar tokoh maupun kader PKS di dalam merespon ideologi PKS hari ini. Menurut Imdadun Rakhmat, PKS memiliki 
berbagai agenda dakwah, antara lain menegakkan syariat Islam, menegakkan sistem pemerintahan Islam dan khilāfah islāmiyyah (Rahmat, 2008). Sikapsikap individual kader PKS sangat memimpikan terwujudnya khiläfah islāmiyyah.

Latar belakang Ketua Majelis Syuro PKS, Hilmi Aminuddin juga mendorong publik berspekulasi bahwa PKS tidak dapat dilepascan dari citacita mendirikan Negara Islam. Hilmi adalah anak Danu Muhammad Hasan yang merupakan tokoh NII di Jawa Barat. Meski Hilmi sudah kerap membantahnya, kaitan Hilmi dengan NII akan menjadi beban sejarah yang sulit dihilangkan. Potensi PKS untuk tidak setia kepada Pancasila dianggap sangat tinggi.

Meski banyak kader PKS menolak dikaitkan dengan cita-cita iqāmat aldawlah al-islāmiyyah, bagi mereka, Pancasila bukanlah harga mati. Artinya, masih mungkin Pancasila diganti dengan ideologi lain. Pandangan ini melahirkan sikap mengambang menyangkut penerimaan Pancasila sebagai ideologi negara (Rahmat, 2008). Sebagai ideologi bangsa, Pancasila sejatinya dapat menjadi nation ethics (etika berbangsa) yang harus dijunjung oleh semua komponen bangsa. Nation ethics dalam konteks multikulturalisme bangsa harus mencerminkan, meminjam istilah John Rawls, overlapping concensus (kesepakatan yang bertumpukan). Oleh karena itu, tidak ada cara lain yang sudah teruji dalam sejarah Indonesia, kecuali menjadikan Pancasila sebagai common ground dan common platform di mana semua warga berhak ikut serta dalam permainan di dalamnya. Atau, merevitalisasi fungsi Pancasila sebagai public ethics bagi bangsa Indonesia.

Pada dasarnya, Pancasila merupakan konsensus nasional yang memuat nilai-nilai "kebaikan bersama” sebagai dasar pemersatu suatu negara. Sebagai sebuah konsensus, apakah Pancasila merupakan falsafah negara atau sekedar persetujuan politik, hal demikian bisa jadi debatable. Tetapi, setiap perjanjian (consensus) adalah suci bagi pihak-pihak yang terikat. Kesucian itu setidaknya menuntut dua hal. Pertama, keharusan untuk melaksanakan isi perjanjian. 
Kedua, larangan untuk mengkhianati isi perjanjian. Kesucian sebuah kesepakatan itu menjadi bentuk moral tertinggi suatu masyarakat.

Dalam konteks di atas, Pancasila merupakan perjanjian suci bangsa yang menjadi dasar kenegaraan Indonesia. Di dalam perjanjian tersebut, disepakati lima hal pokok (lima sila) yang menjadi payung kebersamaan bangsa (mizalat alummah) yang beragam agama, suku dan budaya. Jadi, kesepakatan itu (yang kemudian disebut Pancasila) dasar-dasar untuk hidup bersama Sikap PKS terhadap Pancasila yang mengambang dapat dipandang sebagai praktik taqiyyah politik. Menurut Quraish Shihab, taqiyyah secara bahasa berarti pemeliharaan dan penghindaran (Shihab, 2007) atau penjagaan.

Sikap dan posisi PKS tentang Pancasila dipandang masih dilematis. Asas, visi dan misi PKS tidak sepenuhnya mendukung tegaknya Pancasila sebagai dasar negara. Di dalam diri PKS masih menyimpan cita-cita untuk menegakkan syariat Islam, sekalipun sebagian kader membantahnya. Dilema ini menempatkan Pancasila sebagai bukan keputusan final, dan akan diganti dengan yang lebih baik jika saatnya tiba. Sikap ini menunjukkan bahwa PKS belum menjadi Indonesia lahir dan batin. Keinginan "yang tidak pernah padam" dari sebagian umat Islam untuk memiliki dasar negara Islam merupakan tantangan dan sekaligus peluang menjadikan Pancasila sebagai ideologi yang hidup (living ideology). Oleh karena ia hidup, maka Pancasila bersifat dinamis dan terus-menerus berdialog dengan masyarakat.

\section{SIMPULAN}

Tantangan serius kepartaian hari ini adalah belum jelasnya turunan ideologi dalam bentuk dasar-dasar program kerja (platform). Selain itu terjadi ketidakkongruen antara ideologi dengan kebijakan politik, karena besarnya derajat pragmatisme politik. Karena belum diterjemahkan secara riil, tidak heran bila sulit ditemukan perbedaan antara partai politik yang satu dengan yang lainnya. Padahal titik utama untuk membedakan antara partai yang satu dengan yang lainnya terletak pada, seperti dikemukakan di atas, ideologi dan platform partai politik. Karena ideologi dan platform ini yang menjadi ciri dan 
identitas suatu partai politik, yang membedakan antara yang satu dengan yang lainnya. PDIP, PSI dan PKS memiliki sejatinya memiliki karakter ide politik yang berbeda. Untuk PDIP, AD-ART telah tercantum secara jelas ideologi politik nasionalisme-marhaenisme. Namun peneliti masih menemukan ketidak-korelasian antara teks nasionalis-marhaenisme di AD-ART dengan beberapa kebijakan-kebijakan politik PDIP, baik di skala nasional maupun lokal. Partai Solidaritas Indonesia, karena sebagai partai baru, peneliti lebih banyak menganalisa teks-teks politik PSI melalui AD-ART. Hasilnya, PSI memiliki ide-ide politik yang berhaluan sosialisme demokrasi yang bertujuan pada negara kesejahteraan (welfare state). Terkait kebijakan politik, karena PSI baru pertama mengikuti pemilu 2019, peneliti menyimpulkan bahwa beberapa kasus seperti diskriminasi dan perda syariah di Aceh, PSI merespon dengan ide-ide politik yang khas, yaitu solidaritas dan keadilan sosial. Namun, keputusan PSI berkoalisi dengan pemerintahan Jokowi, yang di beberapa kebijakan, menurut peneliti mencederai nilai-nilai kerakyatan dan keadilan sosial, PSI tidak ada respon.

Peneliti mengkaji literatur PKS dan observasi dinamika kegiatan politik PKS, terutama selama pemilu, menyimpulkan bahwa ideologi PKS yang ketika awal didirikan adalah Islam fundamentalisme bertransformasi menjadi Islam moderat pasca pemilu 2004. Secara internal, hal ini sejatinya menimbulkan friksi antar elit PKS. Sedangkan secara eksternal, PKS memang mampu meraup suara di angka 5 besar karena keluwesannya dalam berkoalisi politik dengan partai nasionalis (non-Islam) seperti Gerindra dan Demokrat di dalam pilpres 2014 dan 2019.

\section{DAFTAR PUSTAKA}

Aminuddin, M. F. (2009). Moh. Fajar Shodiq Ramadlan. 2015.,.. Match-All Party, 39-74.

Aulia, D. (2017). Penguatan Demokrasi: Partai Politik Dan (Sistem) Pemilu Sebagai Pilar Demokrasi. Masyarakat Indonesia, 42(1), 115-126.

Basyir, A. (2017). Ideologi Politik Dilematis Partai Keadilan Sejahtera (Pks) Antara Gerakan Tarbiyah Dan Pragmatisme. In Right: Jurnal Agama Dan Hak Azazi Manusia, 3(2). 
POLITICON : Jurnal Ilmu Politik Vol.1 No.2 ; Hal 135-157

Website : http://journal.uinsgd.ac.id/index.php/politicon ISSN : 2685-6670 ( Online )

Castles, L., \& Feith, H. (1970). Indonesian Political Thinking, 1945-1965. Cornell University Press.

Fukuyama, F. (2006). The End Of History And The Last Man. Simon And Schuster.

Furkon, A. M. (2004). Partai Keadilan Sejahtera: Ideologi Dan Praksis Politik Kaum Muda Muslim Indonesia Kontemporer. Teraju.

Kemenkeu. (2019). Menjawab Utang.

Kurniasih, W. (2019). Studi Orientasi Ideologi Marhaenisme Dewan Pimpinan Daerah Partai Demokrasi Indonesia Perjuangan (Dpd Pdi-P) Provinsi Jawa Tengah. Journal Of Politic And Government Studies, 8(01), 261-270.

Kusuma, H. (2019). Fakta Utang Ri Selama 4 Tahun Jokowi-Jk. Retrieved July 7, 2019, From Detik.Com Website: Https://Finance.Detik.Com/BeritaEkonomi-Bisnis/D-4266062/Fakta-Utang-Ri-Selama-4-Tahun-Jokowi-Jk

Marshall, T. H., \& Bottomore, T. (1992). Citizenship And Social Class.

Novi, D. R. M. (2013). Pks Terbuka Untuk Caleg Non Muslim. Retrieved July 6, 2019, From Republika.Co.Id Website: Https://Republika.Co.Id/Berita/Mkz89p/Pks-Terbuka-Untuk-CalegNon-Muslim

Nurjaman, A. (2016). Peta Baru Ideologi Partai Politik Indonesia. Jurnal Bestari, (42).

Nusantaranews.Co. (2019). Ternyata Logo Psi Sama Dengan Sosialis Internasional. Retrieved July 6, 2019, From Nusantaranews.Co Website: Https://Nusantaranews.Co/Ternyata-Logo-Psi-Sama-Dengan-SosialisInternasional/

Pdip. (2015). Buku Anggaran Dasar Dan Anggaran Rumah Tangga Partai Demokrasi Indonesia Perjuangan Dengan Nomor: 09/Tap/Kongres/PdiP/2015. Di Tetapkan Kongres Iv (2015-2020) Di Bali Bab Iii Arti, Tujuan, Fungsi Dan Tugas Pasal 6 Anggaran Dasar Pdip 2015-2020.

Psi.Id. (2016). Logo Psi. Retrieved June 10, 2019, From Psi.Id Website: Https://Psi.Id/Logo-Psi/

Psi. (2016). Buku Ad/Art Psi. Psi.

Rahmat, M. I. (2008). Ideologi Politik Pks; Dari Masjid Kampus Ke Gedung Parlemen. Lkis Pelangi Aksara. 
POLITICON : Jurnal Ilmu Politik Vol.1 No.2 ; Hal 135-157

Website : http://journal.uinsgd.ac.id/index.php/politicon ISSN : 2685-6670 ( Online )

Schattschneider, E. E. (1960). Party Government... Transaction Publishers.

Shelmi, H. (2019). Berapa Besar Utang Luar Negeri Indonesia Saat Ini? Retrieved July 7, 2019, From Idntimes.Com Website: Https://Finance.Detik.Com/Berita-Ekonomi-Bisnis/D-4266062/FaktaUtang-Ri-Selama-4-Tahun-Jokowi-Jk

Shihab, M. Q. (2007). Sunnah-Syiah Bergandengan Tangan. Mungkinkah: Kajian Atas Konsep Ajaran Dan Pemikiran. Tangerang: Lentera Hati.

Soekarno. (1923). Demokrasi Politik Dan Demokrasi Ekonomi. Retrieved From Https://Tofikpr.Files.Wordpress.Com/2014/03/Dibawahbenderarevolu si-1.Pdf

Yesicha, C. (2019). Marketing Politik Rekrutmen Politisi Perempuan Di Provinsi Riau (Studi Kasus Partai Solidaritas Indonesia Dan Partai Nasional Demokrat). Jurnal Dakwah Risalah, 29(2), 189-201. 